\title{
Saethre-Chotzen syndrome: Case report and literature review
}

\section{Zespół Saethrego-Chotzena - opis przypadku i przegląd piśmiennictwa}

\author{
Anna Pelc ${ }^{A-D}$, Marcin Mikulewicz ${ }^{C-F}$ \\ Department of Maxillofacial Orthopaedics and Orthodontics, Division of Facial Abnormalities, Wroclaw Medical University, Poland \\ A - research concept and design; $\mathrm{B}$ - collection and/or assembly of data; $\mathrm{C}$ - data analysis and interpretation; \\ $D$ - writing the article; $E$ - critical revision of the article; $F$ - final approval of the article
}

Address for correspondence

Anna Pelc

E-mail: anna.pelc@umed.wroc.pl

\section{Funding sources}

None declared

Conflict of interest

None declared

Received on March 7, 2018

Reviewed on April 5, 2018

Accepted on May 15, 2018

\begin{abstract}
Saethre-Chotzen syndrome (SCS) belongs to a group of rare congenital disorders connected with craniosynostosis and syndactyly. The purpose of this paper is to provide a review of the literature, to collect all reported symptoms and to describe the case of an 11-year-old female with SCS. The electronic databases PubMed and Scopus were searched to gain all symptoms of SCS described in the literature. The most common features of SCS described in the literature are synostosis of the coronal suture, syndactyly, facial asymmetry, low hairline, prominent ear crus, prominent nasal bridge, eyelid ptosis, and ocular hypertelorism. Less common symptoms include hearing loss, renal abnormalities and cardiac defects. Intraoral manifestations of SCS include maxillary hypoplasia, mandibular prognathism and high arched palate. Moreover, in some patients mental disability is observed, which may be connected with the size of the deletion in the TWIST gene. There are no pathognomonic symptoms of SCS, which would indicate a diagnostic problem. Our patient displayed small dysmorphic changes within the skull and limbs and proper intellectual development. On the basis of an intraoral, extraoral examination and X-rays, she was diagnosed with relative mandibular prognathism. Currently, she is treated with a removable appliance. This report emphasizes a considerable variability of symptoms in SCS and highlights the most common features.
\end{abstract}

Key words: craniosynostosis, Saethre-Chotzen syndrome, acrocephalosyndactyly, acrocephalosyndactyly type 3

Słowa kluczowe: kraniosynostoza, zespół Saethrego-Chotzena, akrocefalosyndaktylia, akrocefalosyndaktylia typu III
DOI

10.17219/dmp/91050

Copyright

○ 2018 by Wroclaw Medical University

and Polish Dental Society

This is an article distributed under the terms of the

Creative Commons Attribution Non-Commercial License

(http://creativecommons.org/licenses/by-nc-nd/4.0/) 


\section{Introduction}

Saethre-Chotzen syndrome (SCS) (MIM 101400) belongs to a group of rare genetic disorders known as acrocephalosyndactyly, which is characterized by syndactyly and craniosynostosis - the premature fusion of certain cranial sutures. ${ }^{1,2}$ Craniosynostosis can be a part of a genetic syndrome (e.g., Apert, Crouzon, Pfeiffer, SCS) but more often it is an isolated defect - approx. $85 \%$ of all craniosynostosis cases are nonsyndromic. ${ }^{2}$

Saethre-Chotzen syndrome is one of the most common craniosynostosis syndromes and was first described independently by 2 psychiatrists: Haakon Saethre (1931) and Fritz Chotzen (1932) as acrocephalosyndactyly type $3 .^{2}$ The prevalence of SCS is estimated at $1 / 25000$ to $1 / 50000$ of live births. ${ }^{3}$ Saethre-Chotzen syndrome may often go unrecognized, especially in the group that does not experience craniosynostosis and that is the reason why the real number of cases may be higher than estimated. ${ }^{2,4}$ It affects both sexes equally. ${ }^{5}$

Gene mutations were proved to be responsible for SCS - mainly modifications in the TWIST1 gene of chromosome $7 \mathrm{p} 21$, containing the bHLH domain, which is important for the development of the head and limbs and is inherited in an autosomal dominant manner. ${ }^{2,6}$ Rarely, it may also be caused by FGFR2 and FGFR3 gene mutation. ${ }^{7}$ However, occurrences of the novo mutation are also reported. ${ }^{1}$

The characteristic of SCS includes a premature closure of cranial sutures, particularly the coronal suture, which usually begins within the first 12 months of life. This coexists with finger and/or toe abnormalities. Coronal synostosis occurs in $20-30 \%$ of all craniosynostosis cases with females being more often affected than males. ${ }^{2,8,9}$ Intraoral manifestations of SCS include maxillary hypoplasia, mandibular prognathism, and high arched palate. ${ }^{2}$

The aim of this study is to present a case report of a 9-year-old girl with SCS treated in our clinic and to emphasize the wide variability in the phenotypic expression of this syndrome on the basis of literature review.

\section{Case report}

A 9-year-old female was referred to the Department of Orthodontics, Division of Facial Abnormalities (Wroclaw Medical University, Poland) by a general dentist who was concerned about her malocclusion.

According to the medical history, the girl was born in a natural way after 40 weeks of gestation with a birth weight of $3180 \mathrm{~g}$. This was the mother's $3^{\text {rd }}$ pregnancy and the $1^{\text {st }}$ that was full-term. After birth, apart from the features of craniofacial dysmorphism, she was diagnosed with cyanosis, reduced muscle tension, and poor reflexes. Moreover, the girl required pneumonia, respiratory and renal failure treatment shortly after labor. Advanced care was provided and she had been under the care of numerous specialists since she was a neonate: cardiologist due to congenital valvular pulmonary stenosis and interatrial septal defect, endocrinologist because of hypothyroidism and ophthalmologist due to divergent strabismus and myopia. There was no family history of acrocephaly. The parents underwent a genetic test that showed a correct karyotype, indicating that SCS was caused by de novo mutation in the TWIST1 gene.

A general examination revealed features of craniosynostosis and face dysmorphic traits, such as a broad forehead with low hairline, hypotelorism, a "beaked" nose with a depressed nasal bridge, and small low-set ears. The profile of the patient is straight with the light retrusion of the chin (Fig. 1). Finger abnormalities were also present in the form of brachydactyly with a significant shortening of the little finger and nail dysplasia (Fig. 2).

Intraoral examination revealed a high arched palate, crowding in the upper and lower arch, angle class I on both sides, canine class I on the right side, class II on the left side, and a dual tooth 12 . The midline of the lower arch was shifted to the left side and mixed dentition was observed. The deciduous canine, molars, permanent incisors, and first molars in the upper and lower arches were present, which is correct for the patient's age (Fig. 3). In the $1^{\text {st }}$ step of diagnostic imaging, an orthopantomo-

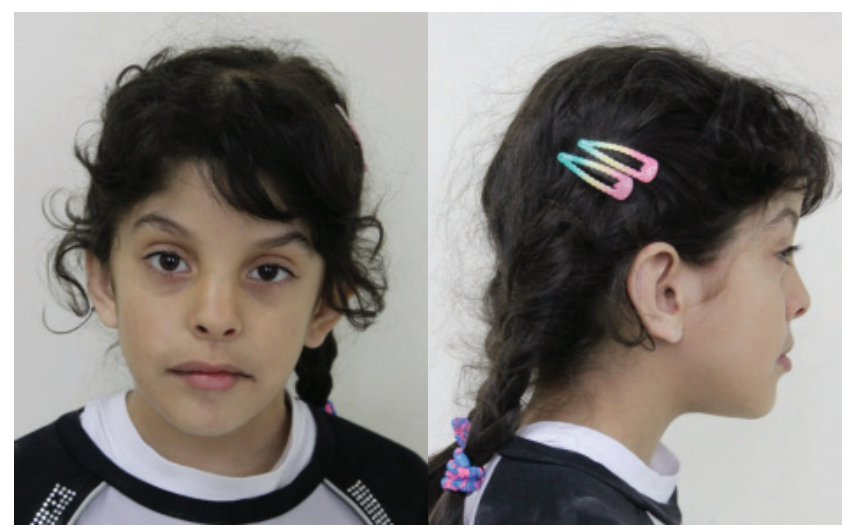

Fig. 1. Extraoral photographs

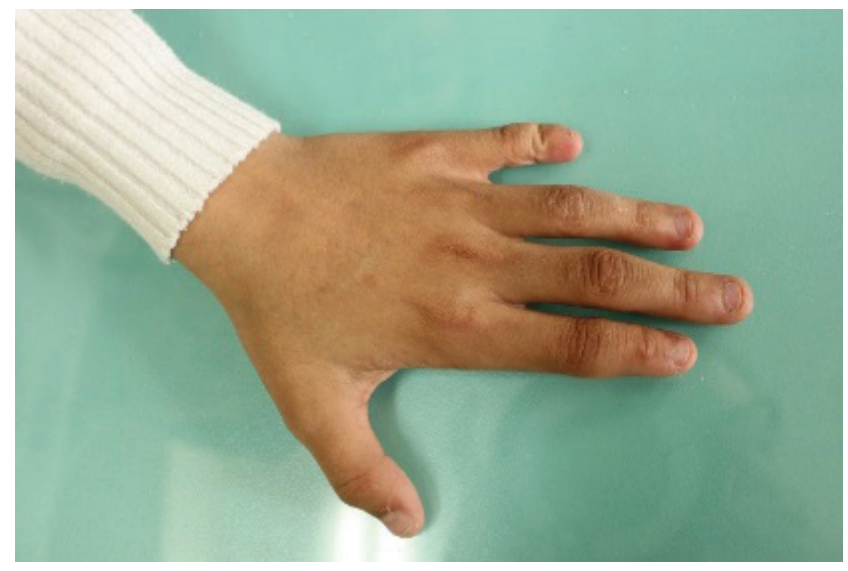

Fig. 2. Fingers abnormalities 


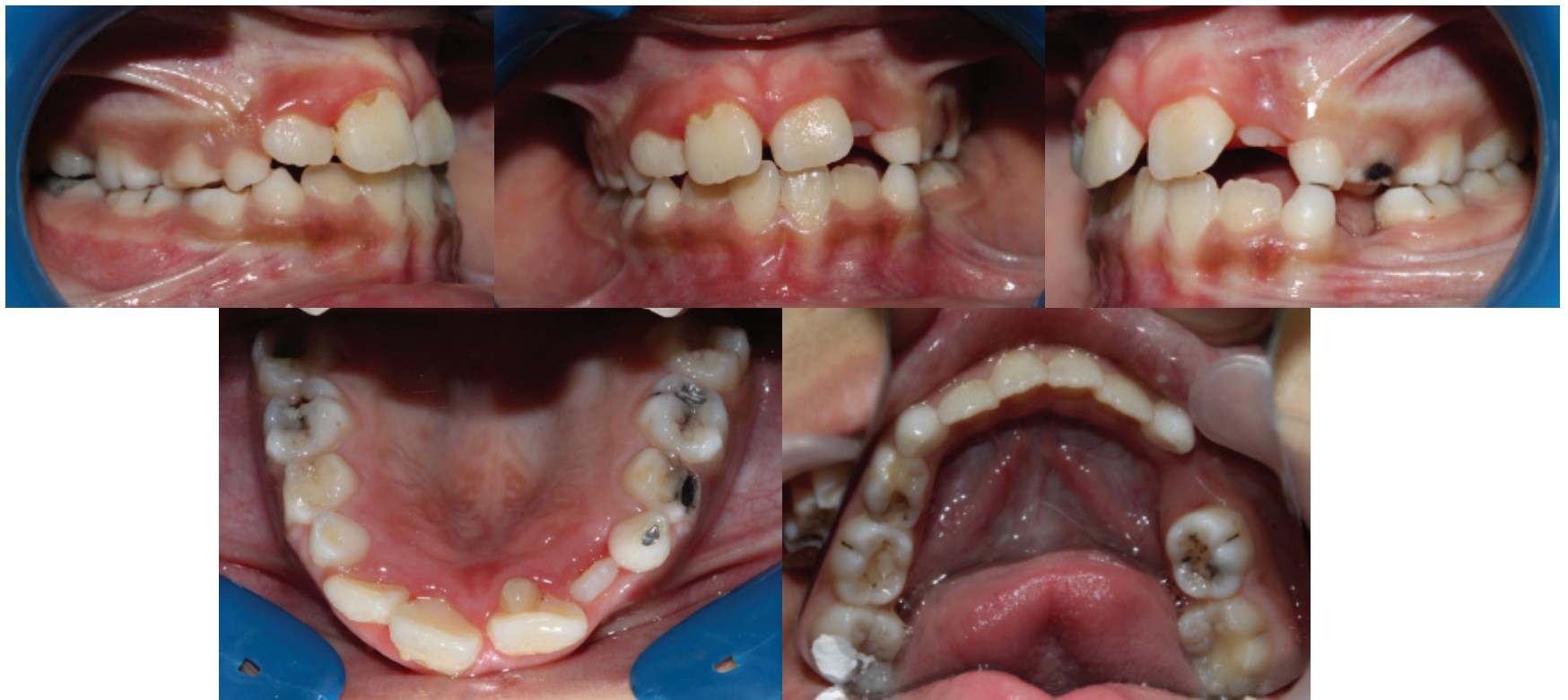

Fig. 3. Intraoral photographs

graph evaluation (Fig. 4) was performed and it demonstrated the presence of all permanent teeth. Poor oral hygiene and severe decay are observed. The calculated DMFT index was 12 indicating the need for conservative treatment of the patient. The cephalometric analysis verified maxillary retrognathia $\left(\mathrm{SNA}=73.0^{\circ}\right)$, mandibular retrognathia $\left(\mathrm{SNB}=75.9^{\circ}\right)$, skeletal class III malocclusion $\left(\mathrm{ANB}=-2.5^{\circ}\right)$, which confirmed relative mandibular prognathism (Fig. 5, Table 1)

A physical examination confirmed by a radiological $\mathrm{X}$-ray showed a lack of the coronal suture. The psychological examination revealed hyperactivity, with no abnormalities in intellectual development. The mother reported that the girl removed her hair excessively, which was confirmed by a bald spot on her head (Fig. 1). Further genetic diagnostics are planned. The diagnosis was performed on the basis of clinical features.

Table 1. Cephalometric measurements of 11-year old patient

\begin{tabular}{|c|c|c|c|c|}
\hline Description & $\begin{array}{l}\text { Cephalometric } \\
\text { measurements }\end{array}$ & Value & Mean & SD \\
\hline \multirow{2}{*}{$\begin{array}{l}\text { Maxilla to } \\
\text { cranial base }\end{array}$} & SNA & $73.0^{\circ}$ & $82.0^{\circ}$ & $\pm 3.0^{\circ}$ \\
\hline & NL-NSL & $9.5^{\circ}$ & $8.0^{\circ}$ & $\pm 4.0^{\circ}$ \\
\hline \multirow{2}{*}{$\begin{array}{l}\text { Mandible to } \\
\text { cranial base }\end{array}$} & SNB & $75.9^{\circ}$ & $80.0^{\circ}$ & $\pm 3.0^{\circ}$ \\
\hline & ML-NSL & $40.7^{\circ}$ & $28.0^{\circ}$ & $\pm 5.0^{\circ}$ \\
\hline \multirow{3}{*}{$\begin{array}{l}\text { Maxilla to } \\
\text { mandible }\end{array}$} & ANB & $-2.0^{\circ}$ & $2.0^{\circ}$ & $\pm 2.0^{\circ}$ \\
\hline & wits & $-4.6^{\circ}$ & $0^{\circ}$ & $\pm 2.0^{\circ}$ \\
\hline & ML- NL & & & \\
\hline \multirow{2}{*}{$\begin{array}{l}\text { Maxillary } \\
\text { dentition }\end{array}$} & U1-NA [mm] & $8.0^{\circ}$ & $3.7^{\circ}$ & $\pm 2.0^{\circ}$ \\
\hline & U1-NA & $30.0^{\circ}$ & $21.0^{\circ}$ & $\pm 4.0^{\circ}$ \\
\hline \multirow{2}{*}{$\begin{array}{l}\text { Mandibulary } \\
\text { dentition }\end{array}$} & L1-NB & $3.1^{\circ}$ & $3.8^{\circ}$ & $\pm 5.0^{\circ}$ \\
\hline & L1-NB & $23.8^{\circ}$ & $24.0^{\circ}$ & $\pm 4.0^{\circ}$ \\
\hline Soft tissue & naso-labial angle & $104.4^{\circ}$ & $110.0^{\circ}$ & $\pm 7.0^{\circ}$ \\
\hline
\end{tabular}

SD - standard deviation.

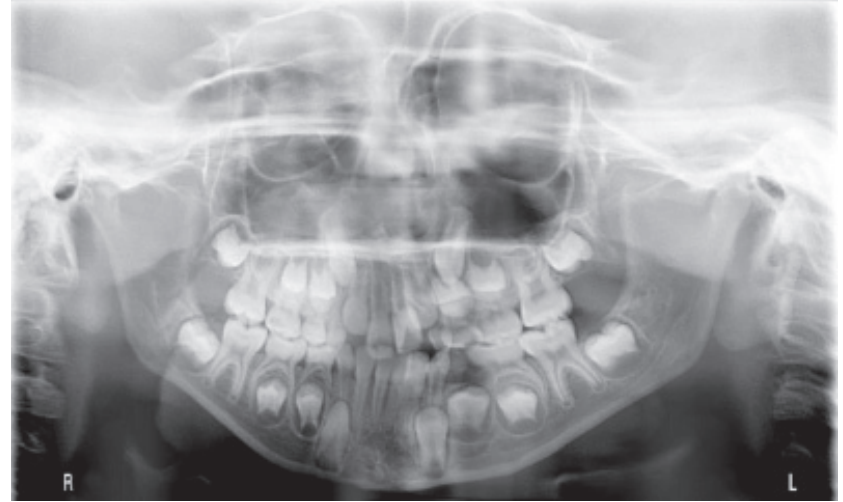

Fig. 4. Orthopantomograph

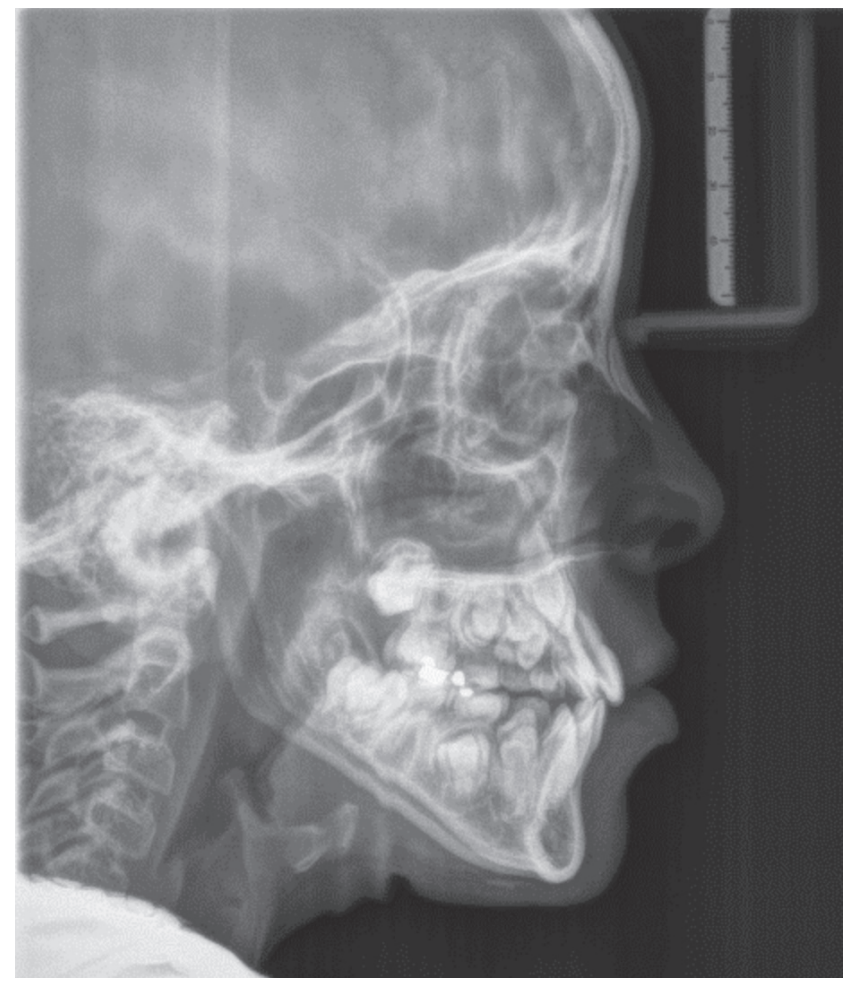

Fig. 5. Lateral cephalometric radiograph 
Table 2. Systematic review from 2000 to 2017

\begin{tabular}{|c|c|c|c|c|c|c|c|c|c|c|c|}
\hline Article & Publication type & A & Details about patients & Genetic confirmation & B & c & $\mathrm{D}$ & $\mathrm{E}$ & $\mathrm{F}$ & G & Conclusion \\
\hline Shimbo et al., $2017^{10}$ & case report & 1 & 15-month-old male & de novo $0.9-\mathrm{Mb}$ microdeletion in $7 \mathrm{p} 21$ & - & - & + & + & + & & HDAC9 was suggested to contribute to developmental delay in SCS patients with $7 \mathrm{p} 21$ microdeletions \\
\hline \multirow{4}{*}{$\begin{array}{l}\text { Mitsukawa et al, } \\
20166^{\prime \prime}\end{array}$} & \multirow{4}{*}{ case report } & \multirow{4}{*}{4} & 4-year-old male & \multirow{4}{*}{ mutation in the TWIST gene, 445C>T } & + & + & 0 & + & - & - & \multirow{4}{*}{$\begin{array}{c}\text { familial case report of } 4 \text { individuals with SCS of } 3 \text { generation and surgical management of brachycephaly and } \\
\text { blepharoptosis in these patients }\end{array}$} \\
\hline & & & 11-year-old male & & + & + & 0 & + & - & - & \\
\hline & & & 45-year-old female & & + & + & 0 & - & - & - & \\
\hline & & & 72-year-old female & & 0 & + & 0 & - & - & - & \\
\hline \multirow{5}{*}{ Tahiri et al., $2015^{12}$} & \multirow{5}{*}{ case report } & & 7-year-old female & \multirow{2}{*}{$\begin{array}{l}\text { duplication of } 21 \text { bp from nucleotide } 396 \text { to } 416 \text { of the TWIST gene } \\
\text { resulting } \\
8.72 \mathrm{Mb} \text { de novo deletion in } 7 \mathrm{p} 21.2 \mathrm{p} 15.3\end{array}$} & 0 & + & - & 0 & - & - & \multirow{5}{*}{$\begin{array}{l}\text { new and unique pattern of sutural fusion "peace sign synostosis" (PSS) characterized by synostosis of the metopic, } \\
\text { bicoronal and sagittal sutures }\end{array}$} \\
\hline & & & 13-month-old male & & 0 & + & & 0 & - & - & \\
\hline & & 5 & 18-month-old male & I point mutation in the TWIST gene c.421 G $\rightarrow$ A & 0 & + & - & 0 & - & - & \\
\hline & & & 9-month-old male & 12Mb 7p21.1:7p15.1 deletion & 0 & + & & 0 & - & - & \\
\hline & & & 10-month-old male & 1.0Mb interstitial deletion of $7 \mathrm{p} 21.1240 \mathrm{~kb}$ away from the TWIST gene & 0 & + & - & 0 & - & - & \\
\hline Di Rocco et al., $2015^{13}$ & case report & 1 & 22-month-old male & 0 & - & + & + & - & - & - & $\begin{array}{l}\text { case of a patient with complex craniosynostosis with a unique antenatal progressive fusion of both coronal } \\
\text { sutures and of the metopic suture with an absence of mental retardation }\end{array}$ \\
\hline Shimada et al., $2013^{14}$ & case report & 1 & 5-year-old male & microdeletions in 4913.2 and $7 \mathrm{p} 21.1$ & - & + & - & + & - & - & case report of the patient with a typical SCS phenotype and additional severe neurological features \\
\hline Cho et al., $2013^{15}$ & case report & 1 & 16-month-old boy & deletion of $148 \mathrm{~kb}$, involving TWIST1 & - & + & - & + & - & - & $\begin{array}{l}\text { Sizes important contribution of array CGH to the ident } \\
\text { even in a patient not showing the phenotypet }\end{array}$ \\
\hline Zechi-Ceide et al., $2012^{16}$ & ${ }^{6}$ case report; research support & 1 & 15-year-old female+ & 7 p21 and 3p21.31 microdeletion & + & + & + & + & - & - & patient displays clinical findings that fit into both diagnoses: SCS and hyper IgE syndrome \\
\hline Spaggiari et al., $2012^{17}$ & case report & 1 & 23 weeks of gestation & $\begin{array}{l}11.4 \mathrm{Mb} \text { deletion from } \mathrm{nt} 17,042,756 \text { to } \mathrm{nt} 28,465 \\
\text { chromosomal region 7p15.1-p21.1. }\end{array}$ & - & + & + & 0 & - & 0 & $\begin{array}{c}\text { first prenatal case of a de novo molecularly well delineated TWIST1 gene deletion asso } \\
\text { The pregnancy was terminated }\end{array}$ \\
\hline Fryssira et al., $2011^{18}$ & case report & 1 & newborn boy & $\begin{array}{l}\text { microdeletion on chromosome } 7 \text { p21.1- }-14.3 \text { detected by array-CGH } \\
\text { and encompassing the TWIST and HOXA gene cluster }\end{array}$ & - & + & + & 0 & + & - & $\begin{array}{l}\text { patient with a combined phenotype of SSS and hand-foot-uterus syndrome. Deletition encompassed } 74 \text { genes } \\
\text { and caused haploinsufficiency of g genes known to be implicated in different autosomal dominant genetic } \\
\text { disorders: TWIST, DFNAS, CYCS, HOXA11, HOXA13, and GARS }\end{array}$ \\
\hline De Jong et al., $2011^{19}$ & research support & 21 & 0 & 0 & 0 & 0 & 0 & 0 & 0 & 0 & moderate hearing loss was diagnosed in $28.6 \%$ of patients with SCS \\
\hline \multirow{3}{*}{ Rosen et al., $2011^{20}$} & \multirow{3}{*}{ comparative study } & \multirow{3}{*}{29} & 12 males & 0 & $62 \%+$ & & & & & & \multirow{3}{*}{$\begin{array}{l}\text { most patients with SCS suffered from hearing loss at some point during their childhood, but it usually resolved. } \\
\text { Research shows that } 59 \% \text { of patients had at least a abnormal audiogram, but } 72 \% \text { had normal hearing on their } \\
\text { last audiogram }\end{array}$} \\
\hline & & & 17 females & 0 & $38 \%-$ & 0 & 0 & 0 & 0 & 0 & \\
\hline & & & from 0.7 to 24.5 years & 0 & & & & & & & \\
\hline \multirow[t]{2}{*}{ De Marco et al., $2011^{21}$} & case report; research support & 1 & 5-year-old female & de novo balanced translocation 46, XX, t(7;:12)(p21.2;p12.3 & - & + & & - & - & - & $\begin{array}{l}\text { confirmatory case report providing further evidence for TWISTI haploinsufficiency in SCS, and a possible role } \\
\text { of PTP-oc as a genetic factor underlying or at least influencing the development of craniosynostosis }\end{array}$ \\
\hline & \multirow{3}{*}{ case report; research support } & \multirow{3}{*}{3} & 2-year-8-month-old female & 11.7Mb deletion in the 7p21.2p15.2 & - & - & + & + & - & - & \multirow{3}{*}{ clinical manifestations of SCS depend of the deletion size } \\
\hline \multirow[t]{2}{*}{ Busche et al., $2011^{22}$} & & & 1-year-8-month-old female & $526 \mathrm{~kb}$ deletion in the 7p21.1 & 0 & - & - & - & - & \multirow{2}{*}{$\begin{array}{l}\text { hypo- } \\
\text { dontia }\end{array}$} & \\
\hline & & & 16-year-old male & $9.2 \mathrm{Mb}$ deletion in the chromosomal region $7 \mathrm{p} 15.2 \mathrm{p} 21.1$ & 0 & + & + & + & & & \\
\hline Lamônica et al., $2010^{23}$ & case report; research support & \multicolumn{2}{|c|}{$\begin{array}{c}45-\text {-year-old female (mother) } \\
11 \text {-year-old male (son) } \\
\text { 12-year-old female (daughter) }\end{array}$} & $\begin{array}{l}\text { Pro } 136 \text { His mutation } \\
\text {. }\end{array}$ & + & + & + & + & - & - & $\begin{array}{l}\text { report suggests that there may be a correlation between Pro } 136 \text { His mutation and hearing loss } \\
\text { in a patient with SCS }\end{array}$ \\
\hline Foo et al., 200924 & case report & 22 & birth - 32-year-old & $\begin{array}{l}\text { 23\% complete deletions of the TWISTI gene; } 77 \% \text { unique missense, } \\
\text { nonsense, insertion, or intragenic deletion mutation of the TWISTI1 } \\
\text { gene. }\end{array}$ & 0 & + & + & + & + & - & different locations of the TWIST1 gene mutation in this study did not correlate to a specific surgical outcome \\
\hline De Jong et al., $20092^{25}$ & research support & 35 & & 0 & 0 & 0 & 0 & 0 & 0 & 0 & refractive error 14 of 27 (52\%); strabismus 13 of 3 . \\
\hline Peñ et al., 20092 ${ }^{6}$ & case report & 1 & 3-week-old female & $\begin{array}{l}\text { novel sequence variant, c.G572T, predicting p.R191M in the TWIST } \\
1 \text { gene }\end{array}$ & + & + & + & + & - & - & $\begin{array}{l}\text { vith cinical eatures of SCS who } \\
\text { in the TWIST gene, corres: }\end{array}$ \\
\hline Stoler et al., $2008^{27}$ & $\begin{array}{l}\text { case report; comparative } \\
\text { study }\end{array}$ & 51 & & 0 & 0 & 0 & 0 & 0 & 0 & 0 & high-arched palate in $43 \%$, bifid uvula in 10\%, cleft palate in $6 \%$ \\
\hline $\begin{array}{l}\text { Schlut-Bolard et al., } \\
2008^{28}\end{array}$ & case report; research support & 1 & 4.5-year-old male & $\begin{array}{l}\text { translocation between the short tarms of chromosomes } 2 \text { and } 7 \text { and } \\
\text { an insertion of the } 7(\text { q } 21.39222) \\
690 \mathrm{~kb} \text { deletion in } 7 \mathrm{p} 21.3 \text { involving the TWIST gene }\end{array}$ & - & + & + & + & - & - & case report of a patient with characteristic features of SCS diagnosed by array CGH \\
\hline Raybud et al., $2007^{29}$ & review & 2 & 6 years; 14 years & $\begin{array}{c}0 \\
0\end{array}$ & 0 & 0 & 0 & 0 & 0 & 0 & $\begin{array}{l}\text { neurological non-specific finding about the presence of a mega cisterna magna and poor contrast } \\
\text { for age between the grey and white matter }\end{array}$ \\
\hline Shetty et al., $2007^{30}$ & research support & 1 & female infant & 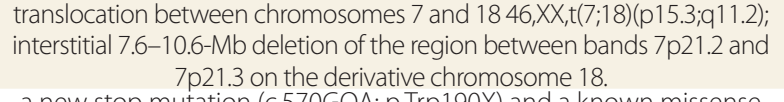 & - & + & + & + & - & - & patient with a complex mutation of genes and serious symptoms of SCS \\
\hline Seifert et al., $2006^{31}$ & case report & 1 & 5-year-old female & $\begin{array}{l}\text { a new stop mutation (c.570GAA; p.Trp 190X) and a known missense } \\
\text { mutation (c.379GOC; p.Ala1 27Pro) in }\end{array}$ & - & + & + & & - & - & case of a patient with SCS associated with metastatic renal cell carcinoma originating in the right kidney \\
\hline $\begin{array}{l}\text { Defr } \\
\text { Def }\end{array}$ & research support & 24 & 0 & Q289P mutation in the FGFR2; $3 / 24$ & + & $24 / 24$ & 24/24 2 & 2/24 & - & - & case report of 4 families suffering from SCS \\
\hline De Heer et al., $2004^{33}$ & case report & 13 & 0 & small mutation in TWIST gene & + & $2 / 13$ & $12 / 13 \mathrm{c}$ & 0/13 & 0 & 0 & a large 5-generation family with characteristics of SCS \\
\hline & & & $1-13$ years old & mutation in TWIST gene $2 / 11$ & $1 / 2$ & $1 / 2$ & $1 / 2$ & $0 / 2$ & - & - & \\
\hline Chun et al., $2002^{34}$ & research support & 11 & 7 females & deletion in TWIST gene 3/11 & $1 / 3$ & $3 / 3$ & $2 / 3$ & $3 / 3$ & 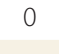 & 0 & $\begin{array}{l}\text { in situ hybridization (FISH) for deletion detection of TWIST, is sufficient to detect mutations in }>80 \% \text { of patients } \\
\text { with the Saethre-Chotzen phenotype }\end{array}$ \\
\hline Dollfus et al., $2002^{35}$ & & & 4 males & no mutation $6 / 11$ & $2 / 6$ & $6 / 6$ & $3 / 6$ & $1 / 6$ & 0 & 0 & \\
\hline Dollfus et al., $2002^{35}$ & research support & 16 & & 0 & + & $4 / 16$ & $3 / 16$ & 0 & - & - & 4-generation Indian family \\
\hline Lee et al., $2002^{36}$ & case report; review & 1 & & TWIST mutation & - & + & + & - & - & 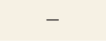 & patient with a severe profound sensorineural hearing loss \\
\hline Boeck et al., $2001^{37}$ & case report & 2 & $\begin{array}{l}\text { l-year-old male } \\
\text { female (mother) }\end{array}$ & 11 bp deletion in TWIST gene & \pm & \pm & - & \pm & - & - & combination of SCS and rare primary immunodeficiency in a 7-year-old boy \\
\hline
\end{tabular}

+ present; - absent; 0 no information. SCS - Saethre-Chotzen syndrome. A - No. of patients; B - family history; C - craniosynostosis; D - limb abnormalities; E - mental retardation; F - cleft; G - dental abnormalities. 
Currently, the patient is under the care of our clinic and is treated with a removable expansion appliance - a Schwartz plate with a Fischer screw, which is activated once every 2 weeks (Fig. 6).

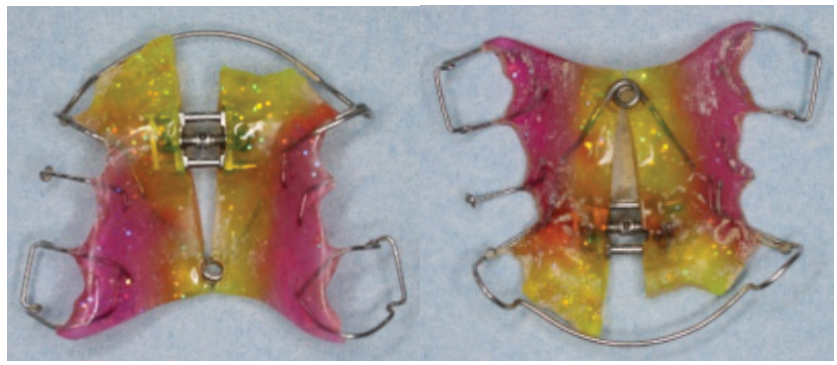

Fig. 6. Schwartz plate

\section{Literature review}

The electronic databases - PubMed and Scopus were searched from years 2000 to 2017. The language of the articles was restricted to English. The following keyword was used for the search: "Saethre-Chotzen syndrome”. 170 articles from PubMed, 199 articles from Scopus were initially included in the study. Then, references of the articles were searched manually. The inclusion criteria were as follows: case reports with described features of the syndrome in detail; articles on the frequency of occurrence of a particular feature, review of the literature focused on SCS. The exclusion criteria: not enough details about the patients, animal studies, studies focused on genetic diagnostic methods (Table 1).

Twenty eight articles ${ }^{10-39}$ were finally chosen after applying the selection criteria and removing duplicated papers (Fig. 7, Table 2). The above-mentioned articles, which described more than 10 cases of SCS, were additionally screened to show the frequency of the most common features (Table 3). ${ }^{24,34,35,38,39}$

\section{Discussion}

Saethre-Chotzen syndrome belongs to a group of rare genetic disorders known as acrocephalosyndactyly disorders. This genetic condition is characterized by the premature fusion of certain bones of the skull (at 1-3 years of age) and the fusion of certain fingers or toes. ${ }^{40}$ The most common is the premature fusion of the coronal suture, which is located between the frontal bone and the parietal bone and is perpendicular to the sagittal suture. ${ }^{3}$ These changes can result in various cranial dysmorphologies depending on where the premature closure of the coronal suture occurs: acrocephaly, which includes the premature closure of the coronal sutures alongside any other suture, like the

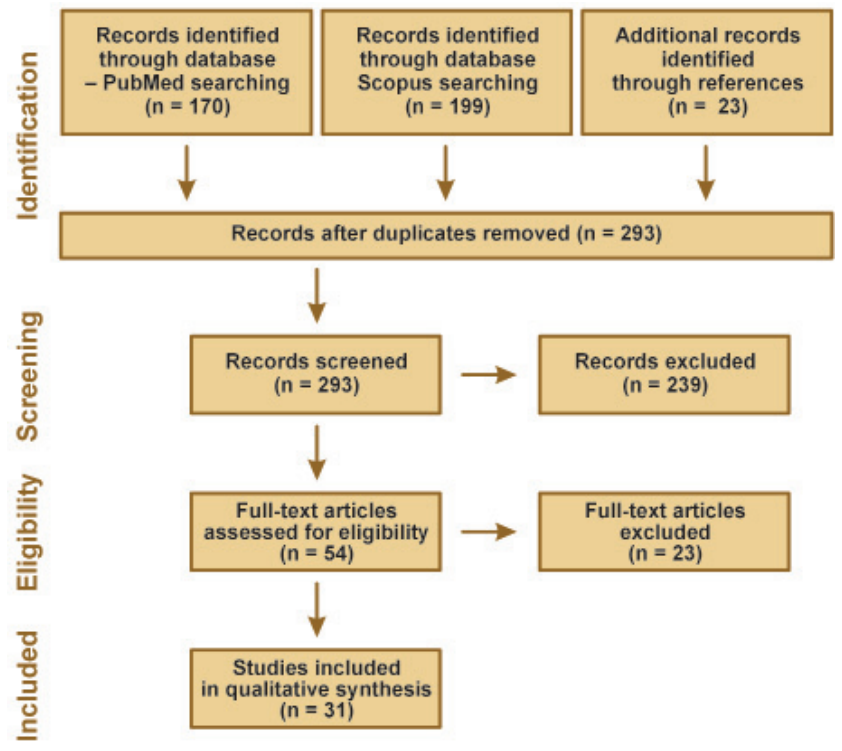

Fig. 7. PRISMA flow diagram

Based on Moher D, Liberati A, Tetzlaff J, Altman DG, The PRISMA Group (2009). Preferred Reporting Items for Systematic Reviews and Meta-Analyses: The PRISMA Statement. PLoS Med 6(7): e1000097.

doi:10.1371/journal.pmed1000097

lambdoid, resulting in an abnormally high, peaked, or cone-shaped cranium, ${ }^{6}$ and brachycephaly, where the premature fusion of the coronal sutures includes both the right and the left side of the skull. ${ }^{2}$ In rare cases, trigonocephaly, cloverleaf deformity, and oxycephaly can also be observed. ${ }^{4}$ In some cases the cranial sutures may fuse unequally and thus contribute to facial asymmetry. Asymmetric craniosynostosis is called plagiocephaly and it occurs in approx. $25 \%$ of patients suffering from SCS. ${ }^{4}$ An early fusion of cranial sutures may lead to increased pressure within the skull (intracranial pressure) and contribute to neurological disorders. According to De Jong et al., SCS is associated with a $21 \%$ risk of elevated intracranial pressure (ICP). ${ }^{25}$

Despite the improper shape of the skull, many abnormalities relating to the face may be observed: a broad forehead with a low hairline, small, low-set ear, and many defects of the nose such us a "beaked" nose, deviated nasal septum, and a depressed nasal bridge.

When it comes to the eyes, ocular hypertelorism (widely spaced eyes), unusually shallow eye cavities (orbits), ptosis (drooping or falling of the upper eyelids), and strabismus were observed. ${ }^{25}$ Moreover, a nasolacrimal duct stenosis causing decreased tear secretion and susceptibility to eye infections may be presented., ${ }^{3,41}$

Many individuals with SCS demonstrate hypoplastic maxilla and midface hypoplasia with relative mandibular prognathism. Moreover, a highly arched palate may be observed. According to Stoler et al., it occurs in $43 \%$ of cases. ${ }^{27}$ In rare cases, cleft palate is diagnosed, which is described by Stoler et al. in $6 \%$ of patients, while a bifid uvula was observed in $10 \%$ of cases. ${ }^{27}$ 
Table 3. Phenotypic representation

\begin{tabular}{|c|c|c|c|c|c|c|}
\hline Phenotype & Dollfus et al. ${ }^{35}$ & Nascimento et al. ${ }^{38}$ & Heer et al. ${ }^{33}$ & De Heer et al. ${ }^{39}$ & Chun et al. ${ }^{34}$ & Foo et al. ${ }^{24}$ \\
\hline Number of patients & 16 & 24 & 13 & 32 & 15 & 22 \\
\hline $\begin{array}{l}\text { Cranial features } \\
\text { craniosynostosis } \\
\text { other }\end{array}$ & $\begin{array}{c}\text { 25\% oxycephaly } \\
-\end{array}$ & $\stackrel{-}{100 \% \text { brachycephaly }}$ & $\begin{array}{c}15 \% \\
-\end{array}$ & $\begin{array}{c}7 \\
\text { 4\% brachycephaly }\end{array}$ & $\begin{array}{c}100 \% \\
60 \% \text { brachycephaly }\end{array}$ & $\begin{array}{c}100 \% \\
-\end{array}$ \\
\hline Facial asymmetry & N/A & $83 \%$ & $85 \%$ & N/A & $73 \%$ & $59 \%$ \\
\hline $\begin{array}{l}\text { Ears features } \\
\text { prominent ears crus } \\
\text { low set ears } \\
\text { different ears anomalies }\end{array}$ & $\begin{array}{c}69 \% \\
\mathrm{~N} / \mathrm{A} \\
37 \% \text { small ears }\end{array}$ & $\begin{array}{c}62.5 \% \\
58 \% \\
42 \% \text { posterior rotated ears }\end{array}$ & $\begin{array}{l}69 \% \\
\text { N/A } \\
\text { N/A }\end{array}$ & $\begin{array}{l}56 \% \\
\text { N/A } \\
\text { N/A }\end{array}$ & $\begin{array}{l}\mathrm{N} / \mathrm{A} \\
20 \% \\
27 \%\end{array}$ & $\begin{array}{l}64 \% \\
\text { N/A } \\
\text { N/A }\end{array}$ \\
\hline Maxillary hypoplasia & $\mathrm{N} / \mathrm{A}$ & $54 \%$ & $\mathrm{~N} / \mathrm{A}$ & N/A & N/A & $0 \%$ \\
\hline $\begin{array}{l}\text { Nose features } \\
\text { prominent nasal bridge } \\
\text { nasal septal deviation } \\
\text { beaked nose }\end{array}$ & $\begin{array}{l}\text { N/A } \\
75 \% \\
\text { N/A }\end{array}$ & $\begin{array}{c}54 \% \\
37.5 \% \\
29 \%\end{array}$ & $\begin{array}{l}\text { N/A } \\
\text { N/A } \\
\text { N/A }\end{array}$ & $\begin{array}{l}65 \% \\
\text { N/A } \\
\text { N/A }\end{array}$ & $\begin{array}{l}\text { N/A } \\
\text { N/A } \\
\text { N/A }\end{array}$ & $\begin{array}{l}\text { N/A } \\
\text { N/A }\end{array}$ \\
\hline $\begin{array}{l}\text { Eyes features } \\
\text { eyelid ptosis } \\
\text { occular hypertelorism } \\
\text { epicanthus } \\
\text { strabismus } \\
\text { ocular hypotelorism } \\
\text { downslanting palpebral fissures } \\
\text { lacrimal duct stenosis } \\
\text { proptosis } \\
\text { blepharophimosis }\end{array}$ & $\begin{array}{c}93 \% \\
\text { N/A } \\
\text { N/A } \\
\text { N/A } \\
\text { N/A } \\
\text { N/A } \\
\text { N/A } \\
18 \% \\
12.5 \%\end{array}$ & $\begin{array}{c}50 \% \\
46 \% \\
17 \% \\
12.5 \% \\
4 \% \\
\text { N/A } \\
\text { N/A } \\
\text { N/A } \\
\text { N/A }\end{array}$ & $\begin{array}{c}85 \% \\
23 \% \\
8 \% \\
\text { N/A } \\
\text { N/A } \\
15 \% \\
8 \% \\
\text { N/A } \\
54 \%\end{array}$ & $\begin{array}{l}53 \% \\
\text { N/A } \\
\text { N/A } \\
\text { N/A } \\
\text { N/A } \\
\text { N/A } \\
\text { N/A } \\
\text { N/A } \\
\text { N/A }\end{array}$ & $\begin{array}{l}53 \% \\
53 \% \\
13 \% \\
20 \% \\
\text { N/A } \\
\text { N/A } \\
\text { N/A } \\
\text { N/A } \\
\text { N/A }\end{array}$ & $\begin{array}{l}82 \% \\
\text { N/A } \\
\text { N/A } \\
27 \% \\
\text { N/A } \\
73 \% \\
\text { N/A } \\
\text { N/A } \\
\text { N/A }\end{array}$ \\
\hline $\begin{array}{l}\text { Limbs abnormalities } \\
\text { cutaneous syndactyly } \\
\text { clinodactyly } \\
\text { broad great toes } \\
\text { cutaneous syndactyly of the feet } \\
\text { brachydactyly } \\
\text { single transverse palmar crease } \\
\text { digit form thumb } \\
\text { broad thumb } \\
\text { bifid digit externity }\end{array}$ & $\begin{array}{c}100 \% \\
81 \% \\
93 \% \\
\text { N/A } \\
100 \% \\
\text { N/A } \\
\text { N/A } \\
\text { N/A } \\
18 \%\end{array}$ & $\begin{array}{c}79 \% \\
54 \% \\
54 \% \\
37.5 \\
25 \% \\
25 \% \\
21 \% \\
8 \% \\
\text { N/A }\end{array}$ & $\begin{array}{c}8 \% \\
15 \% \\
\text { N/A } \\
\text { N/A } \\
69 \% \\
\text { N/A } \\
\text { N/A } \\
\text { N/A } \\
\text { N/A }\end{array}$ & $\begin{array}{l}\text { N/A } \\
\text { N/A } \\
\text { N/A } \\
\text { N/A } \\
\text { N/A } \\
\text { N/A } \\
\text { N/A } \\
\text { N/A } \\
\text { N/A }\end{array}$ & $\begin{array}{l}27 \% \\
33 \% \\
27 \% \\
\text { N/A } \\
20 \% \\
33 \% \\
\text { N/A } \\
\text { N/A } \\
\text { N/A }\end{array}$ & $\begin{array}{c}27 \% \\
18 \% \\
\text { N/A } \\
\text { N/A } \\
4,5 \% \\
\text { N/A } \\
\text { N/A } \\
\text { N/A } \\
\text { N/A }\end{array}$ \\
\hline Other mental retardation & N/A & $8 \%$ & $0 \%$ & N/A & $27 \%$ & $27 \%$ \\
\hline Epilepsy & N/A & $4 \%$ & N/A & N/A & N/A & N/A \\
\hline High arched palate & $69 \%$ & N/A & N/A & $\mathrm{N} / \mathrm{A}$ & N/A & N/A \\
\hline Lowset hairline & $\mathrm{N} / \mathrm{A}$ & $50 \%$ & $\mathrm{~N} / \mathrm{A}$ & $56 \%$ & $27 \%$ & 63.6 \\
\hline Hearing loss & N/A & N/A & N/A & N/A & $33 \%$ & $27 \%$ \\
\hline Heart defects & $\mathrm{N} / \mathrm{A}$ & N/A & $\mathrm{N} / \mathrm{A}$ & $\mathrm{N} / \mathrm{A}$ & $7 \%$ & $4.5 \%$ \\
\hline Cleft palate & N/A & N/A & N/A & N/A & N/A & $14 \%$ \\
\hline Dental malocclusion & N/A & $21 \%$ & N/A & N/A & N/A & N/A \\
\hline
\end{tabular}

Dental anomalies in a patient with SCS were reported first by Goho. ${ }^{42}$ A characteristic dental feature of this anomaly is the presence of teeth with broad, bulbous crowns, long, narrow tapering roots, and multiple pulp stones in the pulp chambers of all posterior teeth. ${ }^{42}$ Moreover, in patient with SCS, we can notice the absence of certain teeth or supernumerary teeth. ${ }^{40}$ Unfortunately, $42 \%$ of patients with craniosynostosis require restorative treatment, but poor oral hygiene and high plaque accumulation are not connected with the presence of syndactyly. ${ }^{43}$ These dental findings may influence dental care for these patients.
The hands and feet may also be affected by SCS. The most common defects are brachydactyly (unusually short digits) and cutaneous syndactyly of certain fingers and toes, which is usually observed between the $2^{\text {nd }}$ and $3^{\text {rd }}$ fingers and $2^{\text {nd }}$ and $3^{\text {rd }}$ toes and, less frequently, from the $2^{\text {nd }}$ to the $4^{\text {th }}$ fingers. ${ }^{3,41}$ Less frequent signs include clinodactyly of the $5^{\text {th }}$ fingers (abnormally bent or curved fingers), "finger-like" thumbs and broad, deviating great toes. ${ }^{38}$

The disorder is also associated with musculoskeletal abnormalities including a union or fusion of certain bones of the spinal column within the neck, short stature, an 
abnormal fusion of the forearm bones, limited extension of the elbows or knees, short collarbones, and hip deformities. ${ }^{3,41}$ Trusen et al. reported that pathognomonic signs in the skeletal system for SCS are a triangular shape of the epiphysis and a duplicated distal phalanx of the hallux. ${ }^{41}$

Less common symptoms of SCS involve hearing loss, kidney abnormalities, and heart defects. ${ }^{36}$ In the literature we can observe that SCS is associated with a higher risk of breast cancer. ${ }^{7}$ However, James et al. ${ }^{44}$ showed that breast cancer risk is not increased in patients with a TWIST mutation.

Most people with this condition display normal intellectual development, but mild-to-moderate disabilities are possible. Some authors reported that children affected by SCS suffer from mental disability and exhibit autistic behavior. ${ }^{45}$ The literature features some explanations that SCS caused by microdeletion can affect mental disability. ${ }^{46}$ It has been described that the deletion of the TWIST1 gene contributes to significant developmental delay and most patients with intragenic mutation do not show severe developmental delay. ${ }^{10,45,47}$ Shimbo et al. suggested that the developmental delay in SCS patients is connected with a mutation of HDAC 9, which is responsible for the regulation of neocortical neuronal development. ${ }^{10}$ Fehlow et al. ${ }^{48}$ suggested that in patients with SCS, excessive anxiety, obsessions, compulsions, phobias, irritability, and depression may be displayed.

\section{Differential diagnosis}

The diagnosis of patients with SCS is difficult, because the symptoms vary to a large extent from person to person, including affected members of the same family. The differential diagnosis includes other syndromes belonging to a group of craniosynostosis, like Crouzon syndrome, Apert syndrome, Pfeiffer syndrome, Antley-Bixler syndrome, Muenke syndrome, Baller-Gerold syndrome, Robinow-Sorauf syndrome. All these syndromes are characterized by the premature fusion of certain bones of the skull during development, which affects the shape of the head and face. The strong correlation between the genotype and phenotype is only observed in Apert syndrome, where 2 mutations in Ser252Trp and P253 are connected with a larger incidence of cleft palate in the $1^{\text {st }}$ mutation and syndactyly in the $2^{\text {nd }}$ mutation. In the other syndromes, the correlations between phenotype and genotype are less clearly marked. The researchers indicate that some craniosynostosis, which differ clinically, may show identical mutations or be allelic diseases.

\section{Conclusions}

Saethre-Chotzen syndrome reveals a huge variability of symptoms (Table 3). Depending on the degree of severity, they can be mild, sometimes even undetectable, or very advanced causing numerous physical defects and mental retardation. Patients suffering from SCS require long-term care from many specialists. Our patient exhibited minor dysmorphic changes within the skull and limbs and proper intellectual development, which is the reason why we can identify the severity of her condition as mild. Furthermore, despite the fact that craniosynostosis usually requires a complex orthodontic therapy, only a minor malocclusion and dental abnormalities have been reported in the presented patient.

\section{References}

1. Clauser L, Galiè M, Hassanipour A, Calabrese O. Saethre-Chotzen syndrome: Review of the literature and report of a case. J Craniofac Surg. 2000;11:480-486.

2. Heuzé Y, Holmes G, Peter I, Richtsmeier JT, Jabs E.W. Closing the gap: Genetic and genomic continuum from syndromic to nonsyndromic craniosynostoses HHS Public Access. Curr Genet Med Rep. 2014;1:135-145.

3. Gallagher ER, Ratisoontorn C, Cunningham ML. Saethre-Chotzen Syndrome. 2003 May 16 [Updated 2012 Jun 14]. In: Adam MP, Ardinger HH, Pagon RA, et al., eds. GeneReviews ${ }^{\circledR}$ [Internet]. Seattle (WA): University of Washington, Seattle; 1993-2018. Available from: https://www.ncbi.nlm.nih.gov/books.

4. Mulliken JB, Gripp KW, Stolle CA, Steinberger D, Müller U. Molecular analysis of patients with synostotic frontal plagiocephaly (unilateral coronal synostosis). Plast Reconstr Surg. 2004;113:1899-909.

5. Chun K, Teebi AS, Jung JH, et al. Genetic analysis of patients with the Saethre-Chotzen phenotype. Am J Med Genet. 2002;110:136-143.

6. Reardon W, Winter RM. Saethre Chotzen Syndrome. J Med Genet. 1994;31:393-396.

7. Sahlin $P$, Tarnow $P$, Martinsson T, Stenman G. Germline mutation in the FGFR3 gene in a TWIST1-negative family with Saethre-Chotzen syndrome and breast cancer. Genes Chromosomes Cancer. 2009;48:285-288.

8. Hunter AG, Rudd NL. Craniosynostosis. II. Coronal synostosis: Its familial characteristics and associated clinical findings in 109 patients lacking bilateral polysyndactyly or syndactyly. Teratology. 1997;15:301-309.

9. Lajeunie E, Le Merrer M, Bonaiti-Pellie C, Marchac D, Renier D. Genetic study of nonsyndromic coronal craniosynostosis. Am J Med Genet. 1995;55:500-504.

10. Shimbo H, Oyoshi T, Kurosawa K. A contiguous gene deletion neighboring TWIST1 identified in a patient with Saethre-Chotzen syndrome associated with neurodevelopmental delay. Possible contribution of HDAC9. Congenit Anom (Kyoto). 2017;58:33-35.

11. Mitsukawa N, Hayashi T, Satoh K. A familial case of Saethre-Chotzen syndrome in Japan. Neurosurg Q. 2016;26:99-102.

12. Tahiri Y, Bastidas NM, McDonald-McGinn DM, et al. New pattern of sutural synostosis associated with TWIST gene mutation and Saethre-Chotzen syndrome: Peace sign synostosis. J Craniofac Surg. 2005;26:1564-1567.

13. Di Rocco F, Benoit A, Vigneron J, et al. Y-craniosynostosis by premature fusion of the metopic and coronal sutures: A new nosological entity or a variety of Saethre-Chotzen syndrome? Birth Defects Res A Clin Mol Teratol. 2015;103:306-310.

14. Shimada S, Okamoto $\mathrm{N}$, Nomura $\mathrm{S}$, et al. Microdeletions of $5.5 \mathrm{Mb}$ (4q13.2-q13.3) and 4.1 Mb (7p15.3-p21.1) associated with a Saethre-Chotzen-like phenotype, severe intellectual disability, and autism. Am J Med Genet. 2003;161A:2078-2083.

15. Cho E, Yang TH, Shin ES, et al. Saethre-Chotzen syndrome with an atypical phenotype. Identification of TWIST microdeletion by array CGH. Childs Nerv Syst. 2013;29:2101-2104.

16. Zechi-Ceide RM, Rodrigues MG, Jehee FS, et al. Saethre-Chotzen phenotype with learning disability and hyper IgE phenotype in a patient due to complex chromosomal rearrangement involving chromosomes 3 and 7. Am J Med Genet. 2012;158A:1680-1685. 
17. Spaggiari E, Abourac A, Sinico M, et al. Prenatal diagnosis of a 7p15-p21 deletion encompassing the TWIST1 gene involved in Saethre-Chotzen syndrome. Eur J Med Genet. 2012;55:498-501.

18. Fryssira $H$, Makrythanasis $P$, Kattamis $A$, et al. Severe developmental delay in a patient with 7p21.1-p14.3 microdeletion spanning the TWIST gene and the HOXA gene cluster. Mol Syndromol. 2011;2:45-49.

19. De Jong T, Toll MS, de Gier HHW, Mathijssen IMJ. Audiological profile of children and young adults with syndromic and complex craniosynostosis. Arch Otolaryngol Head Neck Surg. 2011;137:775-778.

20. Rosen H, Andrews BT, Meara JG, et al. Audiologic findings in SaethreChotzen syndrome. Plast Reconstr Surg. 2011;127:2014-2020.

21. De Marco P, Raso A, Beri $S$, et al. A de novo balanced translocation $t(7 ; 12)(p 21.2 ; p 12.3)$ in a patient with Saethre-Chotzen-like phenotype downregulates TWIST and an osteoclastic protein-tyrosine phosphatase, PTP-oc. Eur J Med Genet. 2011;54:478-483.

22. Busche A, Graul-Neumann LM, Zweier C, et al. Microdeletions of chromosome 7p21, including TWIST1, associated with significant microcephaly, facial dysmorphism, and short stature. Eur J Med Genet. 2011;54:256-261.

23. Lamônica DAC, Maximino LP, Feniman MR, et al. Saethre-chotzen syndrome, Pro136His TWIST mutation, hearing loss, and external and middle ear structural anomalies: Report on a Brazilian family. Cleft Palate Craniofacial J. 2010;47:548-552.

24. Foo R, Guo Y, McDonald-McGinn DM. The natural history of patients treated for TWIST1-confirmed Saethre-Chotzen syndrome. Plast Reconstr Surg. 2009;124:2085-2095.

25. De Jong T, Bannink N, Bredero-Boelhouwer $\mathrm{HH}$, et al. Long-term functional outcome in 167 patients with syndromic craniosynostosis. Defining a syndrome-specific risk profile. J Plast Reconstr Aesthetic Surg. 2010;63:1635-1641.

26. Peñ WA, Slavotinek A, Oberoi S. Saethre-Chotzen syndrome: A case report. Cleft Palate Craniofacial J. 2010;47:318-321.

27. Stoler JM, Rogers GF, Mulliken JB. The frequency of palatal anomalies in Saethre-Chotzen syndrome. Cleft Palate Craniofacial J. 2009;46;280-284.

28. Schluth-Bolard C, Till M, Labalme A, et al. TWIST microdeletion identified by array CGH in a patient presenting Saethre-Chotzen phenotype and a complex rearrangement involving chromosomes 2 and 7. Eur J Med Genet. 2008;51:156-164.

29. Raybaud C, Rocco C. Brain malformation in syndromic craniosynostoses, a primary disorder of white matter: A review. Childs Nerv Syst. 2007;23:1379-1388.

30. Shetty S, Boycott KM, Gillan TL, et al. Cytogenetic and molecular characterization of a de-novo cryptic deletion of 7p21 associated with an apparently balanced translocation and complex craniosynostosis. Clin Dysmorphol. 2007;16:253-256.

31. Seifert G, Kress W, Meisel C, Henze G, Seeger K. Genetic investigations of Saethre-Chotzen syndrome presenting with renal cell carcinoma. Cancer Genet Cytogenet. 2006;171:76-78.

32. Lopes Burrone De Freitas ÉC, Dantas Nascimento SR, Palandi De Mello M, Gil-Da-Silva-Lopes VL. Q289P mutation in FGFR2 gene causes Saethre-Chotzen syndrome: Some considerations about familial heterogeneity. Cleft Palate Craniofac J. 2006;43:142-147.

33. De Heer IM, Hoogenboom AJM, Eussen HJ, Vaandrager JM, De Klein A. Deletion of the TWIST gene in a large five-generation family. Clin Genet. 2004;65:396-399.

34. Chun K, Teebi AS, Jung JH, et al Genetic analysis of patients with the Saethre-Chotzen phenotype. Am J Med Genet. 2002;110:136-143.

35. Dollfus H, Biswas P, Kumaraamanickavel G, et al. Saethre-Chotzen syndrome: Notable intrafamilial phenotypic variability in a large family with Q28X TWIST mutation. Am J Med Genet. 2002;109:218-225.

36. Lee $S$, Seto $M$, Sie K, Cunningham M. A child with Saethre-Chotzen syndrome, sensorineural hearing loss, and a TWIST mutation. Cleft Palate Craniofac J. 2002;36:110-114.

37. Boeck A, Kosan C, Ciznar P, Kunz J. Saethre-Chotzen syndrome and hyper IgE syndrome in a patient with a novel $11 \mathrm{bp}$ deletion of the TWIST gene. Am J Med Genet. 2001;104:53-56.

38. Nascimento SRD, De Mello MP, Batista JC, Balarin MAS, Gil Da Silva Lopes VL. Clinical findings in four Brazilian families affected by Saethre-Chotzen syndrome without TWIST mutations. Cleft Palate Craniofac J. 2004;41:250-255.
39. De Heer IM, de Klein A, van den Ouweland AM, et al. Clinical and genetic analysis of patients with Saethre-Chotzen syndrome. Plast Reconstr Surg. 2005;115:1894-1905.

40. Matthews-Brzozowska T, Golusik K, Raftowicz-Wójcik K. Presumed Saethre-Chotzen syndrome and Crouzon Syndrome - description of cases [in Polish]. Dent Med Probl. 2005;42:189-193.

41. Trusen A, Beissert M, Collmann H, Darge K. The pattern of skeletal anomalies in the cervical spine, hands and feet in patients with Saethre-Chotzen syndrome and Muenke-type mutation. Pediatr Radiol. 2003;33:168-172.

42. Goho C. Dental findings in Saethre-Chotzen syndrome (acrocephalosyndactyly type III): Report of case. ASDC J Dent Child. 1998;65:136-137.

43. Dalben GS, Costa B, Gomide MR. Oral health status of children with syndromic craniosynostosis. Oral Health Prev Dent. 2006;4:173-179.

44. James PA, Culling B, Mullan G, et al. Breast cancer risk is not increased in individuals with TWIST1 mutation confirmed SaethreChotzen syndrome: An Australian multicenter study. Genes Chromosomes Cancer. 2009;48:533-538.

45. Molpeceres GR, Rodríguez UE, Sanz JLH, et al. A rare case of acrocephaly: Saethre-Chotzen syndrome or Crouzon? J Perinat Med. 2015;43:828.

46. Cai J, Goodman BK, Patel AS, et al. Increased risk for developmental delay in Saethre-Chotzen syndrome is associated with TWIST deletions: An improved strategy for TWIST mutation screening. Hum Genet. 2003;114:68-76.

47. Kress W, Schropp C, Lieb G, et al. Saethre-Chotzen syndrome caused by TWIST 1 gene mutations: Functional differentiation from Muenke coronal synostosis syndrome. Eur J Hum Genet. 2006;14:39-48.

48. Fehlow P, Fröhlich B, Miosge W, Otto W, Walther F. Neuropsychiatrische Begleitsymptome bei Saethre-Chotzen-Syndrom. Fortschr Neurol Psychiatr. 1992;60:66-73. 
